\title{
KOORDINASI PEMERINTAH DAERAH DENGAN LEMBAGA ADAT DALAM PELESTARIAN HUTAN ADAT DI KAWASAN ADAT AMMATOA KAJANG KABUPATEN BULUKUMBA
}

\author{
Faisal1, Andi Nuraeni Aksa², Muh. Ahsan Samad1 \\ 1Program Studi Ilmu Pemerintahan Fakultas Ilmu Sosial dan Ilmu Politik \\ Universitas Muhammadiyah Makassar \\ Jl. Sultan Alauddin No. 259 Makassar 90221 \\ Telp. 0411-866972 ext.107.Fax.0411-8655888 \\ faisal12@yahoo.co.id, ahsansamad@gmail.com \\ ${ }^{2}$ Program Studi Ilmu Administrasi Negara Fakultas Ilmu Sosial dan Ilmu Politik \\ Universitas Muhammadiyah Makassar \\ Jl. Sultan Alauddin No. 259 Makassar 90221 \\ Telp. 0411-866972 ext.107.Fax.0411-8655888 \\ nuraeniaksa@gmail.com
}

\begin{abstract}
The purpose of this study was to determine how the coordination between the Institute of Traditional and Local Government in terms of preservation of Indigenous Traditional Forest Region Ammatoa Kajang Kajang Subdistrict Bulukumba. This type of research is qualitative. The data was analyzed by descriptive qualitative. The results showed that the coordination between the local government with customary institutions in preserving indigenous forests in the area of customs Ammatoa Kajang Bulukumba going well although not maximized. Coordination problems in the indigenous forest conservation Ammatoa Kajang today is the communication has not been smooth due to the ego respective sectoral agencies, the lack of human resources in terms of Konjo language interpreter as well as the distance to the area of customs Ammatoa Kajang far enough.
\end{abstract}

Keywords: coordinating, preservation, indigenous forests, Ammatoa.

\section{ABSTRAK}

Tujuan Penelitian ini adalah untuk mengetahui bagaimana Koordinasi antara Lembaga Adat dengan Pemerintah Daerah dalam hal pelestarian Hutan Adat di Kawasan Adat Ammatoa Kajang Kecamatan Kajang Kabupaten Bulukumba. Jenis penelitian adalah Kualitatif. Data tersebut dianalisis secara Deskriptif kualitatif. Hasil penelitian menunjukkan bahwa koordinasi anatara Pemerintah daerah dengan Lembaga adat dalam pelestarian hutan adat di kawasan adat Ammatoa Kajang Kabupaten Bulukumba berjalan dengan baik walaupun belum maksimal. Kendala koordinasi dalam pelestarian hutan adat Ammatoa Kajang saat ini yaitu komunikasi yang belum lancar disebabkan karena adanya ego sektoral masing-masing lembaga, kurangnya sumber daya manusia dalam hal penerjemah bahasa konjo serta jarak tempuh menuju kawasan adat Ammatoa Kajang yang cukup jauh.

Kata Kunci : koordinasi, pelestarian, hutan adat, Ammatoa. 


\section{A. PENDAHULUAN}

Hutan sebagai karunia dan amanat Tuhan Yang Maha Esa yang dianugerahkan untuk memberikan manfaat serbaguna bagi ummat manusia, karenanya wajib disyukuri, diurus dan dimanfaatkan secara optimal, serta dijaga Pelestariannya untuk sebesar-besar kemakmuran rakyat bagi generasi sekarang dan maupun generasi mendatang. Hutan perlu dijaga pelestariannya dan senangtiasa dipertahankan secara optimal, diurus dengan akhlak mulia, adil, arif, bijaksana terbuka serta bertanggung jawab.

Hutan adalah suatu kesatuan ekosistem berupa hamparan lahan yang berisi sumber daya alam hayati yang didominasi persekutuan alam lingkungannya, yang satu dengan lainnya yang tidak dapat dipisahkan. Kawasan hutan adalah wilayah tertentu yang ditunjuk dan atau ditetapkan oleh Pemerintah untuk dipertahankan keberadaannya sebagai hutan tetap. Penetapan kawasan hutan dengan maksud sebagai kawasan penelitian dan pengembangan, pendidikan dan latihan serta kawasan religi dan budaya. Kawasan hutan religi dan budaya berada pada kawasan hutan adat yang pengelolaannya dimaksud dalam Undang-Undang Republik Indonesia No 41 Tahun 1999 tentang Kehutanan pada poin $\mathrm{f}$ yang kemudian di judicial review UU Kehutanan No 41 Tahun 1999 dimahkamah konstitusi bahwa hutan adat adat adalah hutan negara yang berada dalam wilayah masyarakat hukum adat. Masyarakat hukum adat dalam hutan adat sepanjang menurut kenyataannya masih ada dan diakui keberadaannya berhak melakukan pemungutan hasil hutan untuk pemenuhan kebutuhanhidup sehari-hari masyarakat adat yang bersangkutan, melakukan kegiatan pengelolaan hutan berdasarkan hukum adat yang berlaku dan tidak bertentangan dengan Undang-Undang serta pemberdayaan dalam rangka meningkatkan kesejahteraannya.

Pelestarian hutan adat yang ada di kawasan adat Ammatoa Kajang selama ini tidak lepas daripada adanya kordinasi yang di lakukan oleh pihak Pemerintah Daerah bersama lembaga adat dalam hal pelestarian hutan adat. Kordinasi antara Pemerintah Derah bersama Lembaga adat, hal ini masih perlu ditingkatkan demi tercapainya pelestarian hutan adat yang sesungguhnya sebab masih banyak hal-hal penting untuk di kordinasikan seperti halnya adalah penentuan jumlah luas hutan adat yang sama antara pemerintah daerah dengan lembaga adat.

Kawasan hutan adat Ammatoa Kajang yang luasnya 331,17, Ha, dari total luas desa Tana Toa yakni 1.820 ha yang terdiri atas sembilan dusun yang terbagi atas kawasan dalam (ilalang embaya) dan kawasan luar (pantarang embaya). Masyarakat adat Ammatoa Kajang dalam pelestarian hutan adat dikawasan adat Ammatoa Kajang sangat menghargai dan mematuhi aturan adat dan aturan pemerintah, itu terbukti pada sebuah pasanga' yang berbunyi Pasang Ri Kajang, Punna nanro Tana lanibicara (pasang). Jarunggi Ada'a, Bannang Panjai'i Pammarentaya, mingka punna Pammarentaang lanibicara (Atoran Pammarentah), Nakua Jarunggi Pammarentaya, Bannang Panjai'i Ada'a. Artinya Kalau perkara Tana ingin di bicarakan atau aturan adat (pesan). Adat adalah sebagai jarum penjahit, Pemerintah sebagai benang. Tapi kalau perkara soal Pemerintahan ingin dibicarakan (Aturan Pemerintah) bahwa di katakan pemerintah adalah jarum sedangkan Adat adalah benang penjahit.

Ketaatan masyarakat adat Ammatoa Kajang kepada pemerintah dalam hal pelestarian hutan itu terlihat jelas pada penentuan pall batas yang dibuat dan di tempatkan oleh pemerintah daerah, adanya pembuatan jalan tani melalui Program Pemberdayaan Infrastruktur Pedesaan (PPIP) dengan Program Nasional Pemberdayaan Masyarakat (PNPM) dalam kawasan hutan adat dan aturan lainnya yang dikeluarkan oleh pemerintah baik daerah maupun pusat yang sebenarnya menjadi ancaman pelestarian hutan dan melanggar aturan adat. Ketaatan masyarakat adat dan lembaga adat Ammatoa Kajang kepada 
Pemerintah Daerah itu terkadang tidak berlaku sebaliknya atau kadang kala merugikan pihak masyarakat atau lembaga adat Ammatoa Kajang dalam hal pengambilan keputusan.

Pengambilan keputusan yang diambil kedua pihak antara Pemerintah Daerah dengan Lembaga dat kadang tidak sejalan di antara keduanya karena disebabkan oleh kurangnya koordinasi yang terjalin dalam hal pengambilan keputusan sehingga mengakibatkan kerugian antara kedua belah pihak termasuk oleh pihak lembaga adat itu sendiri. Dalam hal pengambilan keputusan seharusnya antara kedua belah pihak melakukan kordinasi terlebih dahulu sebagai mana seharusnya sehingga apa yang diharapkan oleh pemerintah daerah tidak merugikan pihak lembaga adat begitupun dengan lembaga adat. Sebab koordinasi merupakan hal yang sangat dasar dalam pengambilan kebijakan baik berupa peraturan daerah maupun Peraturan perundang-undangan lainnya.

Koordinasi diartikan sebagai kegiatan yang dilakukan oleh berbagai pihak yang sederajat untuk saling memberi informasi dan mengatur bersama (meyepakati) hal tertentu, sehingga disatu sisi proses pelaksanaan tugas dan keberhasilan pihak yang satu tidak mengganggu proses pelaksanaan tugas dan keberhasilan pihak yang lain, sementara disisi lain yang satu langsung atau tidak langsung mendukung pihak yang lain. Dilihat dari sudut normatif koordinasi diartikan sebagai kewenangan untuk menggerakan, menyerasikan, menyelaraskan dan menyeimbangkan kegiatan-kegiatan yang spesifik atau berbeda-beda agar semuanya terarah padapenyamapaian tujuan tertentu pada saat yang telah ditetapkan.

Peneliti menemukan dari hasil observasi sementara bahwa kurangnya koordinasi yang di lakukan keduanya serta menemuan hasil dari masalah dari koordinasi antara pemerintah daerah dengan lembaga adat, menjadi perhatian serius dalam hal pelestarian hutan adat. walaupun selama ini telah ada upaya yang dijalankan oleh pihak pemerintah dengan lembaga adat Ammatoa Kajang sebagai bentuk kepedulian menjaga Pelestarian hutan adat namun masih dianggap perlu dikembangkan dengan alasan bahwa masih banyak terjadi pelanggaran yang mengancam pelestarian hutan adat dikawasan adat Ammatoa Kajang. Mengakumulasi latar belakang masalah yang terjadi diatas dari observasi awal maka sangat penting rasanya sebagai putera daerah untuk melakukan penelitian mengenai. Koordinasi pemerintah daerah dengan lembaga adat dalam pelestarian hutan adat di kawasan adat Ammatoa Kajang Kecamatan Kajang Kabupaten Bulukumba. Tujuan penelitian adalah Untuk mengetahui bagaimana Koordinasi antara Lembaga Adat dengan Pemerintah Daerah dalam hal pelestarian Hutan Adat di Kawasan Adat Ammatoa Kajang Kecamatan Kajang Kabupaten Bulukumba. Serta untuk mengetahui apa saja yang menjadi kendala dalam pelestarian hutan adat di kawasan adat Ammatoa Kajang Kecamatan Kajang Kabupaten Bulukumba.

\section{B. PENGERTIAN KOORDINASI}

Kata coordination berasal co dan ordinare yang berarti to regulate. Dilihat dari pendekatan empiric dikaitkan dengan segi etimologi koordinasi diartikan sebagai kegiatan yang dilakukan oleh berbagai pihak yang sederajat untuk saling memberi informasi dan mengatur bersama (meyepakati) hal tertentu, sehingga disatu sisi proses pelaksanaan tugas dan keberhasilan pihak yang satu tidak mengganggu proses pelaksanaan tugas dan keberhasilan pihak yang lain, sementara disisi lain yang satu langsung atau tidak langsung mendukung pihak yang lain. Dilihat dari sudut normatif koordinasi diartikan sebagai kewenangan untuk menggerakan, menyerasikan, menyelaraskan dan menyeimbangkan kegiatan-kegiatan yang spesifik atau berbeda-beda agar semuanya terarah pada Penyampaian tujuan tertentu pada saat yang telah ditetapkan.

Menurut Kevin Crowston bahwa Koordinasi (coordinating) adalah proses menghubungkan aktivitas dari berbagai departemen dalam sebuah organisasi.

Secara jelas pengertian koordinasi 
dikemukakan Siagian koordinasi adalah pengaturan tata hubungan dari usaha bersama untuk memperoleh kesatuan tindakan dalam usaha pencapaian tujuan bersama pula. Koordinasi adalah suatu proses yang mengatur agar pembagian kerja dari berbagai orang atau kelompok dapat tersusun menjadi suatu kebutuhan yang terintegrasi dengan cara seefesien mungkin. Koordinasi adalah proses dalam mengintegrasikan seluruh aktivitas dari berbagai departemen atau bagian dalam organisasi agar tujuan organisasi bisa tercapai secara efektif. Sementara itu, mendefinisikan Koordinasi (coordination) sebagai proses pengintegrasian tujuan-tujuan dan kegiatankegiatan pada satuan-satuan yang terpisah (departemen atau bidang-bidang fungsional) suatu organisasi untuk mencapai tujuan organisasi secara efisien. Koordinasi merupakan pengetahuan tata hubungan dari usaha bersama untuk memperoleh kesatuan tindakan dalam memperoleh pencapaian tujuan bersama. Koordinasi merupakan proses yang mengatur pembagian kerja antara individu atau antara kelompok dalam suatu organisasi.

Menurut Terry koordinasi adalah penyerempakan kegiatan-kegiatan secara teratur untuk mewujudkan keseluruhan waktu dan arah yang tepat dalam pelaksanaan, sehingga terdapat tindakan-tindakan yang seragam dan serasi untuk mencapai tujuan yang telah ditetapkan. Dalam koordinasi itu jelas perlu adanya sinkronisasi (syn-sama, chrono-waktu, atau penyerempakan dalam arti melakukan kegiatan secara berbarengan), integrasi (penyatuan tindakan-tindakan) dan simplikasi (penyederhanaan pekerjaan).

Menurut Hasibuan mendefinisikan Koordinasi adalah kegiatan mengarahkan, mengintegrasikan dan mengkoordinasikan unsur-unsur manajemen dan pekerjaanpekerjaan para bawahan dalam mencapai tujuan organisasi. Brech adalah mengimbangi dan menggerakkan tim dengan memberikan lokasi kegiatan pekerjaan yang cocok kepada masing-masing dan menjaga agar kegiatan itu dilaksanakan dengan keselarasan yang semestinya diantara para anggota itu sendiri, dan menurut

Menurut Henry Fayol mendefinisikan proses koordinasi sebagai suatu himpunan dari kegiatan-kegiatan organisasi yang memungkinkan hal tersebut dilaksanakan dengan sukses. Menurut Henry Fayol hal ini membutuhkan: (1) Setiap departemen bekerja sama dengan departemen lain.Setiap departemen, divisi dan sub divisi harus mengetahui bahwa hal itu merupakan pembagian tugas yang biasa. (2) Setiap departemen, divisi, dan sub divisi harus menyesuaikan jadwal pekerjaanya dengan lingkungannya.

Menjurut Thomson terdapat tiga macam saling ketergantungan dalam organisasi untuk melakukan suatu koordinasi yaitu : Pooled Interdepence (saling ketergantungan yang menyatu) Ketergantungan ini terjadi apabila satuansatuan organisasi tidak saling tergantung satu sama lain dalam melaksanakan kegiatan harian, akan tetapi tergantung pada pelaksanaan kerja setiap satuan yang memuaskan untuk hasil akhir. Sequential interdepence (saling ketergantungan yang berurutan) Ketergantungan dalam bentuk ini ditandai dengan dipakainya output suatu bagian sebagai input lainnya. Repicrocal Interdepence (saling ketergantungan yang timbal balik) Ketergantungan semacam ini timbul apabila antar bagian saling mempengaruhi satu sama lain, dan terjadi hubungan saling member dan menerima dalam organisasi.

\section{KONSEP PEMERINTAH DAERAH}

Pemerintah Daerah merupakan salah satu alat dalam sistem penyelenggaraan pemerintahan. Pemerintah daerah ini merujuk pada otoritas administratif di suatu daerah yang lebih kecil dari sebuah negara dimana negara Indonesia merupakan sebuah negara yang wilayahnya terbagi atas daerah-daerah Provinsi. Daerah provinsi itu dibagi lagi atas daerah Kabupaten dan daerah Kota. Setiap daerah provinsi, daerah kabupaten, dan daerah kota mempunyai pemerintahan daerah yang diatur dengan Undang-undang.

Menurut Undang-Undang Nomor 32 Tahun 2004 tentang Pemerintah Daerah, Pemerintah daerah merupakan kepala daerah sebagai unsur penyelenggara Pemerintahan Daerah yang memimpin 
pelaksanaan urusan pemerintahan yang menjadikewenangan daerah otonom. Sedangkan Pemerintahan Daerah adalah penyelenggaraan urusan pemerintahan oleh pemerintah daerah dan Dewan Perwakilan Rakyat Daerah menurut asas otonomi dan tugas pembantuan dengan prinsip otonomi seluas-luasnya dalam sistem dan prinsip Negara Kesatuan Republik Indonesia sebagaimana dimaksud dalam Undang-Undang Dasar Negara Republik Indonesia Tahun 1945.

\section{PENGERTIAN LEMBAGA ADAT}

Lembaga adalah wadah atau tempat orang-orang berkumpul, bekerja sama dan terorganisasi.Lembaga merupakan wadah atau tempat orang-orang berkumpul, bekerja sama secara terorganisasi, terkendali, terpimpin dengan memanfaatkan sumber daya untuk satu tujuan yang sudah ditetapkan (Kamus Besar Bahasa Indonesia).

Pengertian Lembaga Adat menurut Peraturan Menteri Dalam Negeri Nomor 5 Tahun 2007 Tentang Pedoman Penataan Lembaga Kemasyarakatan, Lembaga Adat, lembaga kemasyarakatan baik yang disengaja dibentuk maupun yang secara wajar telah tumbuh dan berkembang didalam sejarah masyarakat atau dalam suatu masyarakat hukum adat tersebut, serta berhak dan berwenang untuk mengatur, mengurus dan menyelesaikan berbagai permasalahan kehidupan yang berkaitan dengan dan mengacu pada adat istiadat dan hukum adat yang berlaku.

Lembaga Adat adalah perangkat organisasi yang tumbuh dan berkembang bersama dengan sejarah suatu masyarakat adat yang mengatur dan menyelesaikan berbagai permasalahan kehidupan sesuai dengan hukum adat yang berlaku.

Dari beberapa pengertian diatas maka dapat disimpulkan bahwa lembaga adat adalah suatu organisai atau lembaga masyarakat yang dibentuk oleh suatu masyarakat hukum adat tertentu yang dimaksudkan untuk membantu pemerintah daerah dan menjadi mitra pemerintah daerah dalam memberdayakan, melestarikan dan mengembangkan adat istiadat yang dapat membangun pembangunan suatu daerah tersebut.
Secara struktural, masyarakat Adat Ammatoa membentuk sebuah lembaga. Pembentukan ini secara rasional cukup jauh dari logika umum dan tidak memeliki latar pendidikan. Hanya saja, mereka mampu menjalankan struktur lembaga tersebut dengan penuh amanah. Masyarakat yang masuk dalam lembaga, akan menjalankan amanah dan tanggungjawab secara jujur dan konsisten. Mereka menghayati dan memahami arti tugas dan tanggungjawabnya. Mereka menjadi orang terpercaya walau pun mereka tidak mengenal sistem pendidikan formal. Mereka hanya berpegang pada pedoman, bahwa adat dan kepercayaan harus dijunjung tinggi dan nilai-nilai harus diaplikasikan dalam kehidupan sehari-hari. Struktur lembaga yang dibentuk oleh masyarakat adat Ammatoa sangat lengkap dengan meterinya. Struktur yang disusun oleh mereka yang tidak mengenyam pendidikan. Pemimpin tertinggi mereka berperan sebagai pelaksana pemerintahan dikawasan adat Ammatoa Kajang, Tana Toa disebut Ammatoa.

Adapun struktur lembaga adat AmmatoaKajang terdiri dari : (1) Ammatoa disamping sebagai penguasa juga sebagai pemimpin spiritual ajaran (paham) adat Ammatoa Kajang sehingga Ammatoa menjadi perpanjangan tangan masyarakat adat untuk meminta perlindungan keselamatan dan kesejahteran dari yang maha kuasa. Ammatoa yang paling berperan memiliki akses dan kontrol terhadap sumberdaya alam yang lebih besar dibanding yang lainnya, Ammatoalah yang menentukan tata guna wilayah dan pemanfaatan sumberdaya alam. Penghargaan dan penghormatan masyarakat Kajang terhadap Ammatoa hingga sekarang masih demikian besar. Ammatoa mempunyai pungsi dan peran sebagai orang yang dituakan, pelindung, pengayom dan suri tauladan bagi seluruh warga masyarakat

\section{a. Struktur Lembaga Adat Ammatoa Kajang}


adat. Sebagai penghubung dan penyelaras antara manusia dengan Turie'a A'ra'na (Yang Maha Kuasa) melalui panganro. Menjadi katup pengaman/penengah ketegangan sosial antar warga masayarakat. Memiliki hak penuh untuk mengangkat dan memberhentikan para pemangku adat Menetapkan seluruh keputusan adat. (2) Anrongta Baku' atoaya dan Anrongta Baku' Aloloa merupakan Ibu bagi seluruh warga masyarakat adat yang dipilih oleh seluruh pemangku adat (Galla), pemilihan Anrongta Baku Atoaya dan Anrongta Baku' Aloloa berdasarkan criteria sebagai kompetensi Pasang dan keturunan yang dimiliki, bukan isteri dari Ammatoa dan atau Pemangku adat. (3) Ada' lima terdiri dari lima orang Gallarang. Salah satu tugas pokok Ada' lima adalah menyangkut pelanggaran dalam kawasan hutan sebagaimana yang disampaikan oleh Ammatoa yang berbunyi “ Appa' Solo' ri Ada'iya, (ada empat perkara yang ditangani langsung oleh Ada' Lima): Tabbang Kaju, Tunu Bani, Rao Doang, Tatta Uhe (Penebangan kayu, pembakaran, pengambilanlebah, penangkapan ikan/udang, pengambilan, pemotongan rotan). (3) Karaeng Tallu memiliki tugas Pokok yang disebut Appa' solo ri Karaengia (ada empat perkara yang ditangani langsung oleh karaeng Tallu): Tuttu', Lahan, Rappa, Tunu Bola (penghinaan, persinahan yang dilakukan oleh orang yang sudah bersuami, perampokan/pencurian,pengrusakan/pembak aran rumah).

Dalam melaksanakan tugas Karaeng Tallu dibantu oleh Adat' tanah yang terdiri dari Galla Ganta, Galla Sangkala, Galla Sapa, Galla Bantalang, dan Loha Karaeng. Kemudian Tutoa Sangkala, Tutoa Ganta Karaeng Pattongko' dan Galla Jojjolo merupakan pemangku adat yang diangkat oleh Ammatoa dan diberikan kewenangan untuk menyelesaikan perkara yang ada di wilayahnya masing-masing.

Peran Lembaga Adat Terhadap Pelestarian Hutan Adat (1) melakukan pengamanan dan perlindungan hutan. (2) Melakukan pengawasan terhadap pemanfaatan hasil hutan (3) Memberikan sanksi bagi yang melanggar aturan adat. (4) Melakukan pengawasan, perlindungan terhadap palleko'na boronga (selimut hutan) dan hutan penyangga. (5) Menentukan waktu kegiatan acara ritual adat dan masyarakat adat dalam kawasan hutan (6) Menetapkan batas luar rambang seppang dan rambang luara.

\section{E. HUTAN ADAT}

Hutan Adat adalah hutan Negara yang berada dalam wilayah masyarakat hukum adat (UU. No. 41 Tahun 1999 Pasal 1, ayat 6). Putusan Mahkamah Konstitusi No.35/PUU-X/2012 tentang judicial review terhadap Undang-Undang Nomor 41 tahun 1999 Tentang Kehutanan menegaskan tentang pengakuan terhadap hutan adat, hutan adat bukan lagi hutan Negara, hutan adat merupakan milik masyarakat hukum adat (yang disebut pula hutan marga, hutan pertuanan, atau sebutan lainnya) berada dalam cakupan hak ulayat karena berada dalam satu kesatuan wilayah (ketunggalan wilayah) masyarakat hukum adat,yang peragaanya didasarkan atas tradisi yang hidup dalam suasana rakyat dan mempunyai suatu badan perurusan pusat yang berwibawa dalam seluruh lingkungan wilayahnya.

Undang-Undang Nomor 41 Tahun 1999 tentang Kehutanan menjanjikan peluang bagi peran serta masyarakat dalam pengelolaan hutan yang lebih beragam demi memberdayakan masyarakat, tetapi pemberdayaan tidak bisa diberikan oleh pihak luar, orang hanya bisa berdaya jika memberdayakan diri sedangkan pemerintah hanya bisa menciptakan lingkungan pendukung yang memungkinkan orang memberdayakan dirinya.

Kebijakan Hutan Adat (HA), Hutan Desa (HD), Hutan Kemasyarakatan (HKm) membuka peluang yang lebih besar kepada masyarakat kampung/adat untuk akses pada dan memegang hak pengelolaan atas sumber daya hutan yang dikuasai Negara dengan jaminan kepastian (secara hukum) yang lebih kuat, meskipun masih mengandung pembatasan-pembatasan. Hutan adat adalah hutan yang dikelola oleh masyarakat hukum adat. Sumber daya alam khususnya hutan memiliki nilai tersendiri dalam kehidupan masyarakat adat Ammatoa Kajang. Bagi masyarakat adat Ammatoa Kajang memanfaatkan hutan dalam keseimbangan agar tetat 
lestari merupakan titah suci dari sang Khalid..

\section{F. METODE PENELITIAN}

Penelitian ini sudah dilakukan berlangsung selama kurang lebih dua bulan dari 11 April sampai 11 Juni 2015. Lokasi Penelitian ini dilakukan Kawasan hutan Adat Ammatoa Kajang Kecamatan Kajang Kabupaten Bulukumba Provinsi Sulawesi Selatan. Untuk memperoleh data tentang koordinasi antara Pemerintah Daerah dengan Lembaga adat dalam Pelestarian hutan adat di kawasan adat Ammatoa Kajang.

Teknik Analisis Data Data, data yang telah terkumpul kemudian dianalisis menggunakan metode deskriftif kualitatif, metode ini mencakup penafsiran terhadap data-data yang terkumpul kemudian dianalisis dan dijadikan sesuai dengan variabel-variabel yang dijadikan indikator dalam penelitian untuk mendapatkan gambaran yang jelas tentang Pelestarian hutan adat di kawasan adat Ammatoa Kajang Kecamatan Kajang Kabupaten Bulukumba.

Teknik Pengumpulan Data menggunakan tiga cara yaitu observasi, wawancara serta dokumentasi. Observasi Pengertian observasi yang lebih sempit ini adalah mengamati (watching) dan mendengar (listening) prilaku seseorang selama beberapa waktu tanpa melakukan manipulasi atau pengendalian, serta mencatat penemuan yang memungkinkan atau memenuhi syarat untuk digunakan ke dalam tingkat penafsiran analisis obyek penelitian yaitu tentang pelestarian hutan adat di kawasan adat Ammatoa Kajang Kecamatan Kajang. Sedangkan wawancara Wawancara merupakan metode pengumpulan data dengan jalan Tanya jawab sepihak yang dilakukan secara sistematis dan berlandaskan pada tujuan penelitian. Dari defenisi tersebut penulis mengadakan wawancara langsung dengan informan yang dinilai dapat memberi informasi tentang Koordinasi Pemerintah Daerah dengan Lembaga adat dalam Pelestarian hutan adat di kawasan adat Ammatoa Kajang Kecamatan Kajang Kabupaten Bulukumba yang akurat dan tepat. Wawancara yang di lakukan terhadap informan yang dipilih antara lain adalah terdiri dari Puto Palasa (Ammatoa), Puto Bolong (Galla Puto), Sultan. S.sos (Galla Lombo), Puto Saguni (Galla Pantama), Puto Toba (Anrong Gurua),
Jumarlin Muslim (Polisi Kehutanan), Jamaluddin .T (Galla Malleleng atau Kepala Desa Malleleng), Andi Buyung Saputra (Camat Kecamatan Kajang). Dokumentasi merupakan pelengkap dari penggunaan observasi dan wawancara dalam suatu penelitian kualitatif. Penulis mengkaji dan menelaah naskah, buku, dan literatur lainnya serta peraturan yang berkenaan dengan Pelestarian hutan adat di kawasan adat Ammatoa Kajang Kecamatan Kajang Kabupaten Bulukumba. Jenis penelitian ini adalah Deskriptif Kualitatif yang bertujuan untuk memperoleh kebenaran pengetahuan yang bersifat ilmiah, melalui prsedur yang telah ditetapkan. Dalam peneitian ini setidaknya ada dua sumber yang digunakan yaitu data primer dari hasil wawancara langsung dengan informan, dan data sekunder dari bahanbahan literature seperti dokumendokumen serta laporan-laporan kepustakaan.

\section{G. HASIL DAN PEMBAHASAN}

Koordinasi antara lembaga atau instansi merupakan suatu hal yang sangat penting dalam rangka pencapaian tujuan bersama, dalam koordinasi juga perlu dilaksanakan manajemen yang baik karena manajemen adalah inti dari pencapaian tujuan suatu organisasi yang telah ditentukan.

Pemerintah Daerah merupakan tingkat pemerintahan yang mempunyai peranan penting dalam pelaksanaan pelayanan penyelenggaraan kepentingan umum. Khusus pada koordinasi pemerintah Daerah denganlembaga adat dalam pelestarian hutan adat di kawasan adat Ammatoa Kajang yang baik dan efektif sangat diperlukan untuk penanggulangan hal tersebut dalam rangka pencapaian tujuan bersama. Berikut adalah wawancara yang dilakukan peneliti dengan pihak Pemerintah Daerah terkait masalah koordinasi pemerintah daerah dengan Lembaga adat dalam 
pelestarian hutan adat Ammatoa Kajang,faktor adapun faktor-faktor yang mempengaruhi koordinasi yaitu kesatuan tindakan, komunikasi, pembagian kerja dan disiplin. Keempat faktor tersebut untuk memastikan sebagai alat ukur untuk melihat secara seksama apakah memang terjalin koordinasi antara pemerintah daerah dengan lembaga adat tersebut yang ada di kawasan adat Ammatoa kajang dalam hal pelestarian hutan adat Ammatoa Kajang sebagai berikut melalui penelitian dengan tekhnik wawancara terhadap informan yang dianggap mampu memberikan informasi yang akurat terhadap pelestarian hutan adat di kawasan adat Ammatoa Kajang,dari keempat faktor tersebut sebagai berikut:

\section{Kesatuan Tindakan}

Kesatuan tindakan merupakan suatu kewajiban untuk memperoleh suatu koordinasi yang baik, jadi dalampelestarian hutan adat oleh pemerintah Daerah dengan lembaga adat harus menyatukan tindakan sehingga segenap kegiatan manajemen maupun kegiatan pelaksanaan satu sama lain tidak simpang siur, tidak berlawanan dan dapat ditujukan kepada titik arah pencapaian tujuan dengan effisien. Kesatuan tindakan dapat menghindari berbagai kemungkinan untuk merugikan pihak yang satu dengan pihak yang lain dalam menjalankan tugas dan fungsinya masing-masing. Dengan adanya kesatuan tindakan untuk pelestarian hutan adat tentu dapat mempermudah terlaksananya kegiatan baik berupa sosialisasi, penerapan aturan adat berupa pasang (pesan), pengawasan, pemberian sanksi kepada masyarakat maupun dalam mengambil tindakan lainnya dalam tujuan pelestarian hutan adat Ammatoa Kajang.

Kesatuan tindakan antara atasan dan bawahan juga juga sangat di perlukan agar terjadi singkronisasi dalam melaksanakan tugas dan fungsi masing-masing demi terwujudnya tujuan dan kepentingan bersama dalam pelestarian hutan adat Ammatoa Kajang. Hasil wawancara dengan Camat Kecamatan Kajang (Labbiria) sebaga berikut:

"Punna lanro Tana lanibicara (pasang).Jarunggi Ada'a, Bannang Panjai'i Pammarentaya, mingka punna Pammarentaang lanibicara (Atoran Pammarentah), Nakua Jarunggi Pammarentaya, Bannang Panjai'i Ada'a.
Artinya Kalau perkara aturan adat ingin di bicarakan ( pesan). Adat adalah sebagai jarum penjahit, Pemerintah sebagai benang. Tapi kalau perkara soal Pemerintahan ingin dibicarakan (Aturan Pemerintah). Bahwa di katakan pemerintah adalah jarum, sedangkan Adat adalah benang penjahit. (Wawancara, $A B$ ).

Diatas ini salah satu Pasang bagi pemimpin/penguasa: Berdasarkan hasil wawancara dari informan dapat disimpulkan bahwa pemerintah Daerah yang diwakili dari pihak Pemerintah Kecamatan Kajang (Labbiria) Daerah Kabupaten Bulukumba selalu melakukan pertemuan dan berkoordinasi bersama antara pihak lembaga adat dengan baik dalam pelestarian hutan adat agar tercipta kesatuan tindakan antara pihak pemerintah dengan lembaga adat .

\section{Komunikasi}

Istilah komunikasi berasal dari bahasa latin "communicatus" yang artinya berbagi atau menjadi milik bersama. Dengan demikian komunikasi berarti suatu upaya yang bertujuan berbagi untuk mencapai kebersamaan. Pengertian lain, Komunikasi adalah, "suatu proses pertukaran informasi diantara individu melalui sistem lambang-lambang, tandatanda, atau tingkah laku. (Rochjat \& Elvinaro. 2011:20)

Pemerintah Daerah dengan Lembaga adat melakukan koordinasi dan hubungan kerja dengan semua pihak yang terkait untuk pencapaian tujuan bersama. Semua pihak yang melakukan koordinasi dan hubungan kerja pada dasarnya melakukan komunikasi. Dalam melakukan komunikasi juga perlu memperhatikan elemen-elemen dan jenis-jenis komunikasi yang ada agar dapat berkomunikasi efektif. Memahami konsep dan batasan/ pengertian komunikasi, juga harus mengetahui secara jelas teknis dan hambatan dalam berkomunikasi. Untuk dapat mencapai keberhasilan dalam pelaksanaan koordinasi dan hubungan kerja, semua pihak harus menyadari dan memperhatikan hambatan-hambatan dan 
teknis-teknis berkomunikasi.

Hubungan komunikasi antara Pemerintah Daerah dengan Lembaga adat yang melaksanakan koordinasi sangatlah penting dan dibutuhkan karena dengan adanya kumunikasi maka bisa berhubungan dengan berbagai pihak dan saling bertukar pikiran, saling memberi masukan yang bisa menambah wawasan dan dapat memberikan solusi atau masukan mengenai tindakan yang akan dilakukan dalam pelestarian hutan adat Ammatoa Kajang. Maka untuk membina hubungan kerja baik antar pihak Pemerintah dengan Lembaga adat Ammatoa Kajang, baik Ammatoa maupun bawahan Ammatoa perlumelakukan komunikasi secara lebih sering dan mendalam mengenai tanggung jawab yang dijalani. Sebagaimana yang dikemukakan salah seorang informandari pihak lembaga Adat Ammatoa Kajang bahwa:

"Alemo sibatang, abulo sipappa, tallang sipahua, manyu siparampe, sipakatau tangga sipakasiri, artinya memupuk persatuan dan kesatuan dengan penuh kekeluargaan dan saling memuliakan".(Wawancara, PB).

Hasil wawancara diatas menunjukkan bahwa memang ada komunikasi antara Pemerintah dengan Lembaga adat, karena pemerintah dengan lembaga adat dianggap sebagai suatu kesatuan keluargaan dan saling memuliakan dalam komunikasi yang di bangun keduanya. komunikasi memang berjalan dengan baik walau masih harus ditingkatkan lagi antara pihak lembaga adat dengan pemerintah itu terbukti dari salah satu pemaparan dari salah satu informan dari pihak lembaga Adat Ammatoa mengatakan bahwa:

"ada' nah pammarenta sitappaki'i ri lalang anjagai borongga inni' nasaba rie nakulle najaga ada rie todo tala nakulle najai ada'. Jari sitappaki taua".Artinya: Adat serta Pemerintah saling percaya dalam menjaga hutan, ini, sebab ada yang bisa di jaga oleh adat, ada pula yang tidak bisa di jaga adat" (Wawancara, PT)

Berdasarkan hasil wawancara diatas, maka pihak lembaga adat dan Pemerintah Daerah saling percaya dalam artian bahwa ada komunikasi yang berjalan baik sehingga pelestarian hutan adat tetap akan terjaga dengan saling membangun kepecayaan sebab pelestarian hutan adat perlu mendapat dukungan pemerintah dalam hal pelestarian hutan adat Ammatoa Kajang.

\section{Pembagian Kerja}

Koordinasi dan hubungan kerja timbul dan sangat dibutuhkan sebagai konsekuensi adanya upaya untuk mencapai tujuan bersama secara efektif dan efisien melalui pembagian tugas. Tugas-tugas ini diwadahkan dalam unitunit sebagai pelaksana dan penanggung jawab satu atau beberapa fungsi. Semua pihak dalam organisasi baik dari pihak pemerintah daerah maupun Ammatoa sebagai pemimpin lembaga adat. Pemerintah daerah dengan Lembaga adat dapat berjalan terpadu, serasi dan selaras dalam pencapaian tujuan dan sasaran bersama dari masing tugas yang menjadi tanggung jawabnya. Sebagaimana pernyataan dari salah satu informan dari pihak Lembaga Adat Ammatoa Kajang, tentang pembagian kerja antara pemerintah daerah dengan lembaga adat dalam pelestarian hutan adat Ammatoa, bahwa:

"Appa' solo' ri ada'iya (ada empat perkara yang langsung disidangkan dilembaga adat/ada' lima):

Tabbang kaju (penebangan pohon), Tatta uhe (potong/pengambilan rotan), Tunu bani (bakar/pengambilan lebah), Rao doang (penangkapan ikan/udang)". (Wawancara, PP)

Berdasarkan hasil wawancara tentang pembagian kerja, maka pihak lembaga adat mengambil peran dalam penindakanjika ada masyarakat yang memanfaatkan hasil hutan tanpa melalui proses perizinan dari lembaga adat Ammato, akan diberikan sanksi sebagaimana yang telah diatur dalam pasang yang di jalankan selama ini secara turung-temurung hingga kini.

\section{Disiplin}


Pada setiap organisasi yang kompleks, setiap bagian harus bekerja secara terkoordinasi, agar masing-masing dapat menghasilkan hasil yang diharapkan. Koordinasi adalah usaha penyesuaian bagianbagian yang berbeda-beda agar kegiatan dari pada bagian-bagian itu selesai pada waktunya, sehingga masing-masing dapat memberikan sumbangan usahanya secara maksimal agar diperoleh hasil secara keseluruhan, untuk itu diperlukan disiplin.

Pemerintah daerah dengan Lembaga adat harus bekerja secara terkoordinasi dan disiplin itu terbukti dengan pelaksanaan tugas dan tanggung jawab yang di amanahkan diantara keduanya, pihak adat menjalankan apa yang telah di pesankan dalam pasang Ammatoa sebagai pemimpin adat Ammatoa Kajang lembaga adat disiplin dalam menjalankan tugas dan menindak lanjuti apa yang telah dianggap melanggar dari aturan pasanga ammatoa dan keputusan adat Ammatoa Kajang yang selama ini di jalankan tanpa melakukan kepemihakan dan kelalaian tugas jika telah di amanahkan tanggung jawab di pundaknya, Ammatoa mengangkat para pembantunya, Ammatoa adalah pemimpin lembaga adat Ammatoa Kajang. Pemangku adat sangat disiplin dalam menjalankan tugas itu terbukti dari salah satu informan dari lembaga adat Ammatoa Kajang mengatakan bahwa:

"Tangurangi mange ri turiea arana, artinya: berarti senangtiasa ingat pada Tuhan Yang Berkehendak. "Alemo sibatang, abulo sipappa, tallang sipahua, manyu siparampe, sipakatau tang sipakasiri, artinya memupuk persatuan dan kesatuan dengan penuh kekeluargaan dan saling memuliakan"."Lambusu kigattang sabara ki pesona, artinya bertindak tegas tetapi juga sabar dan tawakkal"."Sallu riajoka, ammulu riadahang ammaca ere anreppe batu, alla buirurung, allabatu cideng, "artinya harus taat pada aturan yang telah dibuat secara bersama-sama kendati harus menahan gelombang dan memecahkan batu gunung". "Nandigaukang sikontu passuroangto mabuttayya,"artinya melaksanakan segala aturan secara murni dan konsekuen (Wawancara, PP).

\section{Kendala Koordinasi Dalam Pelestarian}

\section{Hutan Adat Di Kawasan Adat Ammatoa Kajang}

Teori Kendala berdasarkan pada ide dasar bahwa tingkat tujuan dibatasi oleh setidaknya satu proses yang menjadi kendala. Hanya dengan menaikkan aliran melalui kendala maka throughput keseluruhan bisa dinaikkan. Anggaplah tujuan organisasi telah dirumuskan. Namun hal itu tidak akan tercapai tanpa mengetahui langkah-langkahnya adalah sebagai berikut:

1. Identifikasi kendala (sumber daya atau kebijakan yang menghalangi organisasi mencapai tujuan)

2. Putuskan bagaimana memanfaatkan kendala (memperoleh kapasitass terbesar pada proses kendala)

3. Jadikan proses-proses yang lain bagian dari keputusan atasan (sejajarkan seluruh sistem atau organisasi untuk menunjang keputusan yang dibuat atasan)

4. Naikkan kendala (lakukan perubahan besar untuk mengatasi kendala)

5. Jika kendala telah teratasi, ulangi tahap 1. Jangan biarkan kelembaman menjadi kendala.

Lima tahap fokus ini bertujuan untuk memastikan upaya-upaya perbaikan yang sedang dilakukan berpusat di sekitar kendala-kendala organisasi. Lima tahap ini disebut sebagai "Proses Perbaikan yang Sedang Berjalan" (Process of Ongoing Improvement)

Kendala pelestarian hutan adat di kawasan adat Ammatoa Kajang seharusnya di fokuskan pada apa yang dianggap menjadi kendalanya utamanya lalu mencari penyelesaian, seperti halnya dalam kurangnya komunikasi yang terjalin antara pemerintah daerah dengan lembaga adat disebabkan karena pihak pemerintah daerah dengan lembaga adat masing-masing mempunyai ego sektoral, kurangnya sumber daya manusia dalam hal penerjemah bahasa Konjo kedalam bahasa Indonesia, serta jarak tempuh yang jauh untuk mencapai kawasan adat Ammatoa dari pusat pemerintahan daerah sehingga menjadi kendala dalam melakukan koordinasi dengan baik 
terhadap pelestarian hutan adat di kawasan Adat Ammatoa Kajang saat ini.

Kendala koordinasi adalah pada hal komunikasi, itu jelas dapat dilihat dari apa yang diungkapkan oleh salah seorang informan yang sekaligus mewakili dari kedua lembaga tersebut dalam hal pelestarian hutan adat di kawasan adat Ammatoa antara pemerintah daerah dengan lembaga adat Adalah sebagai berikut:

"parrallu gitte sanna nipahaminna anggkua terkadang penyusuaian tujuan bersama gitte kunni antara pammarentah na Lembaga ada' itu disebebkan olehsatu hal yang paling penting yaitu punna niitte selama ini, yaitu pada persoalan komunikasi sebenarnya. Makanya itulah parrallu kedde niperlancarki komunikasia gitte kunni antara pammarentah na ada'.Artinya: perlu dipahami bahwa bahwa terkadang penyusuai bersama kita disini anatara pemerintah dengan lembaga adat Adela disebabkan satu hal yang paling penting yaitu jika dilihat selama ini, yaitu persoalan komunikasi sebernya. Makanya itulah perlu sebenarnya diperlancar komunikasi antara pemerintah dengan lembaga adat". (Wawancara. JM).

Hasil wawancara diatas dari pihak Polisi kehutanan, sekaligus mewakili antara dari Pemerintah daerah dengan lembaga adat terhadap pendapat tentang kendala koordinasi dalam pelestarian hutan adat Ammatoa Kajang Adalah karena kurangnya komunikasi antara keduanya sehingga tujuan bersama tidak semuanya bisa tercapai secara maksimal.

\section{PENUTUP}

Koordinasi pemerintah daerah dengan lembaga adat dalam melakukan pelestarian hutan adat Ammatoa Kajang kini sudah berjalan dengan baik walaupun ditemukan hal yang perlu dan harus ditingkatkan lagi dengan melihat empat indikator koordinasi sebagai berikut adalah Kesatuan tindakan pemerintah Daerah dengan lembaga adat seharusnya diperjelas dalam melakukan kegiatan pelestarian hutan adat, Komunikasi pemerintah daerah dengan lembaga adat kita sudah berjalan namun masih harus ditingkatkan lagi. Pembagian kerja pemerintah daerah dengan lembaga adat dalam pelestarian hutan kini berjalan dengan baik serta sesuai dengan tugas dan fungsinya masing-masing dalam pelestarian hutan adat Ammatoa Kajang walaupun masih harus perlu untuk ditingkatkan lagi kedepannya sesuai dengan aturan adat Ammatoa Kajang. serta Disiplin dalam pelestarian hutan adat Ammatoa Kajang masih kurang dilaksanakan secara baik sesuai yang telah diatur dalam pasang jika dari pihak lembaga adat. Namun dari pihak pemerintah daerah hingga kini masih masih menunggu pembahasan acuan hukumnya yaitu RanPerda yang akan nantinya diharapkan menjadi Peraturan Daerah (Perda).

Kendala koordinasi antara pemerintah daerah dengan lembaga adat dalam pelestarian hutan adat Ammatoa Kajang ditemukan. Adapun kendala utamanya adalah persoalan komunikasi yang masih kurang lancar, karena disebabkan adanya ego masing-masing, kurangnya sumber daya Manusia (SDA) Sebagai penerjemah bahasa Konjo kedalam bahasa Indonesia, dan jarak tempuh yang cukup jauh sehingga memakan waktu dan tenaga.

\section{DAFTAR PUSTAKA}

Gibson, Thomas. 2009. Kekuasaan Raja, Syeikh, dan Amtenaar: Pengetahuan Simbolis dan Kekuasaan Tradisional, Makassar: Inninawa.

Rochajat \& Ardianto. 2011. Komunikasi Pembangunan dan Perubahan Sosial. Jakarjat: PT. Raja Grafindo Persada.

Ma'arif Amin, Syamsul. 2003. Journal of Religus Issues, Agama dan Kebenaran. Center For Religious and CrossCultural Studies.

Soekanto, Soerjono 1983. Hukum Adat Indonesia. Jakarta: cetakan ke II. PT 
Raja Grafindo Persada.

Widjaja, Haw. 2012. Undang-Undang Otonomi Desa, merupakan Otonomi yang asli bulat dan utuh. Jakara: PT. Raja Gafindo Persada.

\section{Dokumen :}

Undang-Undang Republik Indonesia Nomor 41 Tahun 1999 Tentang Kehutanan

Undang-Undang No. 32. Tahun 2004 Tentang Pemerintahan Daerah

Peraturan Menteri Dalam Negeri Nomor 5 Tahun 2007 Tentang Pedoman Penataan Lembaga Kemasyarakatan, Lembaga Adat. 